\title{
Hydroxyproline titers in gingival crevicular fluid
}

G. K. Svanberg

University of Michigan School of Dentistry,

Ann Arbor, MI, U.S.A.

\author{
Svanberg GK: Hydroxyproline titers in gingival crevicular fluid. Journal of Peri- \\ odontal Research 1987; 22: 212-214.
}

Inflammation and increased degradation of extracellular matrix resulting in a net loss of collagen are characteristic features of the onset and progression of periodontal diseases. The accumulation of leukocytes and an increased production of hydrolytic enzymes results in a 60 to $70 \%$ loss of collagen at the advancing front of the periodontal lesion (1).

Most of the breakdown products are washed out of the tissue by the inflammatory exudate from the gingival vasculature (2) to appear in the gingival crevicular fluid (GCF). Therefore, the quantification of the breakdown products in the GCF should be a useful tool to monitor loss of extracellular matrix in the gingival connective tissue.

Degradation of collagen can be monitored by the release of hydroxyproline (Hyp) which accounts for about $10 \%$ of this protein. Clq, a subcomponent of the first complement factor, is the only other significant source of Hyp. It contains $4.3 \%$ Hyp by weight (3) and is found coating bacteria in the gingival crevices of patients with chronic periodontitis (4). Consequently, an assay for collagen-derived Hyp in GCF requires the elimination of Clq-derived Hyp.

An assay for collagen-derived Hyp in 1 to $2 \mu$ l volumes of GCF has been established (5) and was used for analysis of samples during the onset and progression of experimental periodontal disease in the beagle dog.

Experimental gingivitis was initiated in 3 female beagle dogs with a healthy periodontium by refraining from all oral hygiene measures. Approximately $1.5 \mu \mathrm{l}$ volumes of GCF were collected from 10 mandibular premolars with microcapillary tubes once every week. After $8 \mathrm{wk}$, cotton floss was applied around the neck of the teeth and left in place for 9 d. GCF was sampled $4 \mathrm{~d}$ after the removal of the ligatures and subsequently at weekly intervals. Blood was collected on each occasion and processed for serum. The dogs were fed no later than $24 \mathrm{~h}$ before samples were collected.

In short, the samples were processed as follows: C1q was precipitated out in $100 \mu \mathrm{l}$ of $0.02 \mathrm{M}$ sodium acetate for 24 $\mathrm{h}$ at $4{ }^{\circ} \mathrm{C}(6)$ and dried aliquots of the supernatants were vapor hydrolyzed with $6 \mathrm{~N} \mathrm{HCl}$ at $105^{\circ} \mathrm{C}$ for $24 \mathrm{~h}$. The samples were brought to dryness twice, the second time after the addition of 25 $\mu$ l of re-drying solution (methanol:water:triethylamine; 2:2:1 by vol.) and derivatized in $25 \mu \mathrm{l}$ of methanol:water : triethylamine : phenylisothiocyanate (7:1:1:1 by vol.) at room temperature for $20 \mathrm{~min}$. The dried samples were dissolved in Waters Sample Diluent:methanol ( $4: 1$ by vol.) for reversed-phase HPLC separation and determination of the phenylthiocarbamyl derivative of Hyp using a Pico-Tag column (Waters Assoc., Milford, MA) kept at $38^{\circ} \mathrm{C}$ with detection at $254 \mathrm{~nm}$. The flow program started isocratic with a mixture of 0.14 $\mathrm{M}$ sodium acetate ( $\mathrm{pH} 6.40$ ), $0.05 \%$ triethylamine and $0.2 \%$ acetonitrile for 4 min, followed by a gradient washing step with $60 \%$ acetonitrile in water (by vol.) for $8.5 \mathrm{~min}$ and a re-equilibration phase for $7.5 \mathrm{~min}$.

Following a pre-experimental period of weekly prophylaxes and daily toothbrushing, the periodontia of the dogs displayed all the clinical signs of health and GCF could not be collected following gentle mechanical stimulation of the gingiva. When oral hygiene measures were abolished, dental plaque accumulated, gingivitis developed, and GCF could be collected without any difficulties after only $1 \mathrm{wk}$ of no oral hygiene.

The titers of what was considered to be collagen-derived Hyp (total Hyp in GCF minus Hyp in serum) fluctuated in an irregular pattern (range 0.7 to 11.0 $\mathrm{ng} / \mu \mathrm{l}$ ) during the onset and progression of experimental gingivitis and averaged $4.7 \pm 2.36 \mathrm{ng} / \mu \mathrm{l}(\overline{\mathrm{x}} \pm \mathrm{SD})$ at wk 8. Four days after the removal of the cotton floss, which had been in place around the neck of the teeth for $9 \mathrm{~d}$, there was a significant $(\mathrm{p}<0.0001$; paired $t$-test $)$ increase to $16.2 \pm 3.45 \mathrm{ng} / \mu \mathrm{l}(\overline{\mathrm{x}} \pm \mathrm{SD})$. During the subsequent 4 -wk period, when no ligatures were present to exacerbate the disease process, GCF from all sites showed decreasing concentrations of Hyp (Fig. 1).

The application of cotton floss ligatures around teeth has been shown to convert stable established gingivitis into destructive periodontitis, the major tissue destruction most likely occurring within the first $4 \mathrm{wk}$ after placement of the ligatures (7). In the present study, GCF samples taken $4 \mathrm{~d}$ after ligature removal had increased concentrations of Hyp, suggesting that they were collected during a phase of increased degradation of extracellular matrix with loss of mature collagen.

Inflamed gingival tissues have increased levels of cAMP (8) that induce enhanced intracellular degradation of newly synthesized collagen (9). It therefore cannot be ruled out that some of the increased concentrations of Hyp in GCF, observed during the destructive phase of experimental periodontal disease, may have been contributed by this process.

Hyp in serum is found in three forms: protein-bound, peptide and free. The protein-bound fraction of serum Hyp in healthy adults shows only minor variations regardless of the diet (10), but $50 \%$ is lost in the precipitation procedure with $0.02 \mathrm{M}$ sodium acetate (11). In order to determine collagen-derived Hyp in GCF, serum Hyp concentration must be subtracted from total Hyp in GCF. Consequently, since C1q was precipitated out of the GCF specimens with $0.02 \mathrm{M}$ sodium acetate, the same procedure had to be applied to the serum samples.

In contrast to protein-bound Hyp, the plasma levels of peptide-Hyp and free Hyp in healthy adults are significantly increased by the intake of Hyp- 


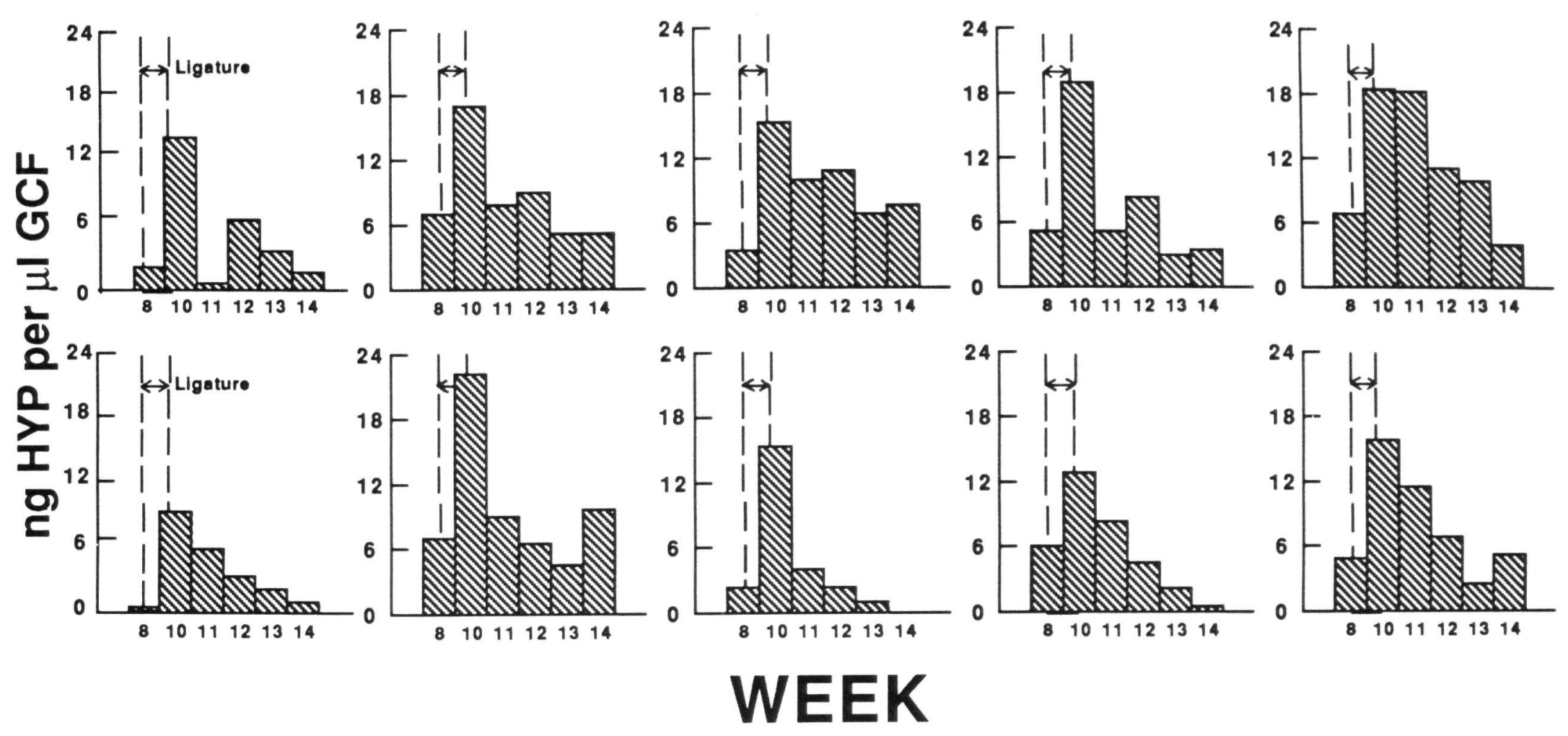

Fig. 1. Changes in collagen-derived Hyp in GCF (total Hyp in GCF minus serum Hyp) during cotton floss ligature-induced periodontitis.
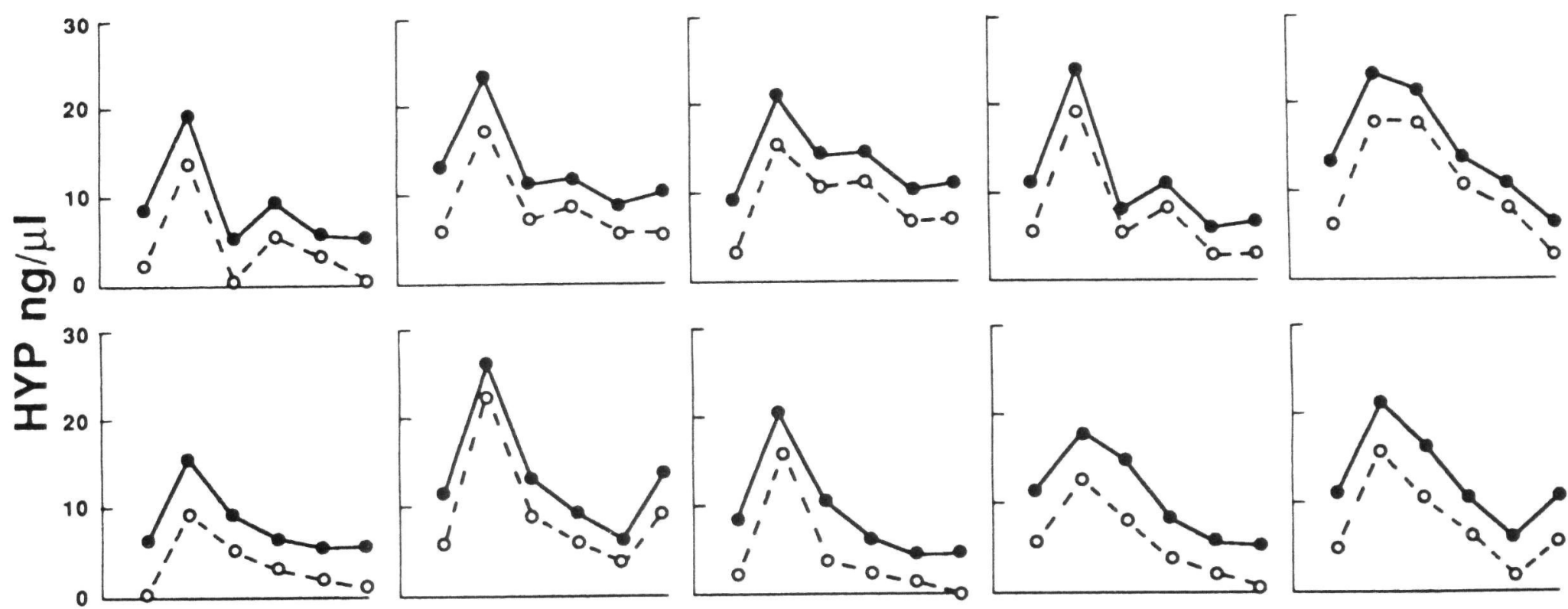

Fig. 2. Concentrations of collagen-derived Hyp in GCF (open circles), defined as total Hyp in GCF minus serum Hyp, and total Hyp in GCF (filled circles). The graphs, generated by weekly determinations of Hyp, follow the same pattern.

containing food but return to baseline values $8 \mathrm{~h}$ (peptide Hyp) and $24 \mathrm{~h}$ (free Hyp) after such food intake (12). Since data on the dietary effects on serum Hyp in the beagle dog are not available, it was assumed that keeping the dogs on a 24-h dietary Hyp restriction would be adequate to establish a reasonably reproducible serum Hyp baseline at the time of sample collection.

Line plots of total Hyp in GCF and collagen-derived Hyp in GCF (total Hyp in GCF minus serum Hyp) show that both graphs follow the same pattern for all sites (Fig. 2). Therefore, total Hyp in GCF can be used to monitor changes in extracellular and intracellular degradation of collagen if dietary Hyp restrictions are implemented. How- ever, determination of collagen-derived Hyp in GCF (total Hyp in GCF minus serum Hyp) would appear to give a more accurate estimate of collagen loss in the periodontal lesion.

\section{Acknowledgment}

This work was supported by NIH Grant DE06953.

\section{References}

1. Schroeder HE, Munzel-Pedrazzoli S, Page RC. 1973. Correlated morphometric and biochemical analysis of gingival tissues. The early lesion in man. Arch Oral Biol 18: 899 .

2. Pashley DH. 1976. A mechanistic analy- sis of gingival fluid production. $J$ Periodont Res 11: 121.

3. Reid KBM, Lowe DM, Porter RR. 1972. Isolation and characterization of $\mathrm{Clq}$, a subcomponent of the first component of complement, from human and rabbit sera. Biochem $J$ 130: 749.

4. Chisikovsky J, Toto PD, Garguilo AW. 1982. C1q and C4 detection on bacterial plaque organisms. J Periodontol 53: 688.

5. Svanberg GK. 1986. Hydroxyproline determination in serum and gingival crevicular fluid. $J$ Periodont Res (in press).

6. Lepow IH, Naff GB, Todd EW, et al. 1963. Chromatographic resolution of the first component of human complement into three activities. $J$ Exp Med 117: 983.

7. Schroeder HE, Lindhe J. 1975. Conversion of stable established gingivitis in the dog into destructive periodontitis. Arch Oral Biol 20: 775. 
8. Elattar TMA, Lin HS. 1981. The relationship between inflammation and cAMP level in human gingiva. Clin $\mathrm{Sci}$ 60: 674 .

9. Baum BJ, Moss J, Breul SD, et al. 1980. Effect of cyclic AMP on the intracellular degradation of newly synthesized collagen. J Biol Chem 255: 2843.

10. LeRoy EC, Sjoerdsma A. 1965. Clinical significance of a hydroxyproline-con- taining protein in human plasma. $J$ Clin Invest 44: 914.

11. Rosano CL, Hurwitz C. 1977. Separation of hydroxyproline-containing protein from C1q (a subcomponent of complement) in serum. Clin Chem 23: 1335.

12. Prockop DJ, Keiser HR, Sjoerdsma A. 1962. Gastrointestinal absorption and renal excretion of hydroxyproline peptides. Lancet 2: 527.
Address:

G. K. Svanberg

University of Michigan School of Dentistry Ann Arbor

MI, 48109

U.S.A. 
This document is a scanned copy of a printed document. No warranty is given about the accuracy of the copy. Users should refer to the original published version of the material. 